\title{
Partnership and Social Capital as the Resources for Pupils' Health and Well-Being in School Communities - A Follow-Up Study in Finland
}

\author{
Hannele Turunen*, Terhi Saaranen and Kerttu Tossavainen \\ University of Eastern Finland, Department of Nursing Science, P.O. Box 1627, FI-70211 Kuopio, Finland
}

\begin{abstract}
The aim of this study was to investigate comprehensive (classes 1-9) school teachers' views of the functionality of the social support networks in promoting pupils' health and well-being in school communities. This study belongs to the European Network of Health Promoting Schools programme (ENHPS) evaluation project in Finland. In this study partnership and the social support networks between home and school, school nurse and school community and school community and various other networks are a part of social capital that promote pupils' health and well-being. The survey data were collected from teachers $(\mathrm{N}=22)$ by the means of web-based questionnaires in the spring terms in a four-year follow-up design. The teachers felt that the social support network and partnership between school and parents and school nurses was significant in promoting the health and well-being of pupils. However, parents and school nurses didn't always have opportunities to participate in the planning and evaluation of teaching and health promotion work in the schools. In the future, partnership will represent a potential way in which schools might build additional capacities and support for promoting pupils' health and well-being. Furthermore, social capital is not separate from other capital structures, such as cultural and economic capital, which are all needed.
\end{abstract}

Keywords: Partnership, pupil, health, well-being, school, social capital.

\section{INTRODUCTION}

In recent years more attention has been placed on the health and well-being of pupils in both Finnish and wider international development, research and policy programs [13]. Learning outcomes in Finland are good, as evaluated by Organisation for Economic Cooperation and Development (OECD) Programme for International Students Assessment (PISA) studies [4]. However, there are problems in the everyday habits of school-aged pupils' health behaviour, like lack of sleeping hours as well as exercise [5]. To change pupils' health behaviour into a more positive direction, numerous improvement proposals have been made (the National Core Curriculum for Basic Education 2004 in Finland) [6]. For example, compulsory health education has been implemented in the Finnish comprehensive schools. In primary schools (classes 1-6, aged 7 to 12 years) health education is integrated with other subjects. In secondary schools (classes 7-9, aged 13 to 16 years) health education is an independent subject and after a transition period (to 2010/2011), the teacher who teaches health education will have to have 60 credits (approximately 1650 hours) of specific studies in school health education [7, 8]. However, pupils' healthy growth and the school day activities of the school staff are being threatened by different challenges, such as a lack of school satisfaction, stress concerning school, bullying, violence and even terrorist acts from outside the school $[5,9,10]$.

It is obvious that the school alone cannot solve the problems related to the threats to pupils' health and

*Address correspondence to this author at the University of Eastern Finland, Department of Nursing Science, P.O. Box 1627, 70211 Kuopio, Finland; Tel: +358 40355 2629; Fax: +358 17162632 ;

E-mail: hannele.turunen@uef.fi well-being, and that's why the school must secure wider cooperation of the homes and school health service and other partners in the workday and operation of the school. In the future the school community must be able to utilise the cooperation of more partners than before also from different levels (for example, home-school co-operation, co-operation with public service branches of the locality and co-operation with the other schools locally, nationally and internationally), because this will make it possible to prevent and anticipate threats that endanger the health and safety of the pupils better and more widely than before.

In Finland, the Basic Education Act 628/1998, revision 477/2003 [11, 12] and the National Core Curriculum for Basic Education [6] standardize teaching and upbringing as the tasks of both the school and the home. The most important themes of the promotion of the health of school communities in Finland have been described in the National Core Curriculum for Basic Education [6] in connection with pupil welfare. For example, every school has to draw up a plan in the curriculum of the school in which the objectives of the school pupils' welfare are described, as to what activities promote health, well-being, security, social responsibility, and interaction in the school community and what type of co-operation there is between pupil welfare personnel and the home, school, pupil welfare experts or other experts, and the local support network [6]. The positive results of the home-school-community connection and the importance of these relations have been brought out in earlier research [13, 14]. Epstein (2001), for example, emphasises that the bridges between home, school, and community are inevitably interconnected [15]. Therefore, it is important to learn about the most effective structures, processes, and practices that will produce good connections and positive 
results with home, school and other partners in promoting pupils' health and well-being.

However, the problem in practice is, and numerous research results also show [13-15], the fact that co-operation between school and home is inadequate in supporting the health learning and well-being of the pupils. Even though collaboration between the home and the school can basically be quite functional and natural (e.g., parents participate in parents' evenings or other school activities), parents usually are not asked to participate in formulating or developing the school curriculum, as the National Core Curriculum for Basic Education requires [16]. Internationally there are partnership approaches and programmes suitable for the school day of the school [17-19], but they are missing nearly totally from Finland. Thus, it is important to identify the social support network and the situation of partnerships and functioning in the school communities, so that partnership programmes which promote pupils' health and well-being can be developed in the future and carried out in practice.

\section{PARTNERSHIP AND THE SOCIAL SUPPORT NETWORKS AS THE RESOURCES IN HEALTH PROMOTION}

So that it will be possible to promote health in school communities in co-operation with different partners, resources are required. Sufficient resources make it possible to carry out the promotion of health. From the viewpoint of resources for the promotion of health and the forming of well-being, the concepts of social, cultural and economic capital have also been brought up [20]. The concept of capital is many-sided and there are many approaches to it; for example, Hancock (2001) has divided the concept of capital into human, natural, economic and social forms [21]. Ferguson (2006) has used the concepts of social, human and financial capital in a review article that deals with social capital and children's well-being [22]. Based on the results of this review article, he further divided social capital into the forms of family social capital and community social capital. The five components of family social capital are family structure, quality of parent-child relations, adult's interest in the child, parents' monitoring of the child's activities and extended family exchange and support. The components of community social capital are social support networks, civic engagement in local institutions, trust and safety, degree of religiosity, quality of school and quality of neighborhood.

Furthermore, Abel (2008) has divided capital into three forms: economic capital (income available for healthy housing, consumption, and recreational activities), social capital (interpersonal support for health enhancing behavior change, knowledge, et al.) and cultural capital (health enhancing values, norms, knowledge and skills) [20]. His thinking is based on the thoughts of cultural capital as resources, especially those of Bourdieu (1986) [23]. However, the one thing observed by the different authors in the articles is that the different forms of capital always affect each other also, even though their concepts or definitions differ from each other. Abel (2008) has examined health and health promotion activities especially from the point of view of cultural capital [20]. In earlier studies social capital, as one form of capital, has been defined as wide welfare-related effects in the promotion of the health and well-being of adults, children and adolescents [22, 24, 25], so it is justified to adapt the theory of social capital also in the well-being and health of school communities. In this article we focus on social capital from the point of view of social support networks and partnership as the resources of the school community's and pupils' health and well-being by applying Abel's model of the forms of capital and contextualizing it in the school community (Fig. 1).

In the background of the social capital theory that has been presented here is the view of Putnam's thinking [26] (cf. in the background of Abel's thinking is Bourdieu's model of thinking). Putnam's definition (1993) is based more on communal properties in which the term of social capital approaches the community and partnership that improves the operation of communities [26]. Thus, social capital is based, for example, on the solidarity and partnership which will be created in interaction networks when certain conditions (trust, open communication, interaction, participation and learning) dominate between people in the school communities [27]. In general this means that only partnership that is based on trust, open communication and continued interaction and participation and learning can expand social capital in the school community and within different levels with other partners, such as other schools and experts in different fields. Thus, good partnership serves as an affirmative resource when pupils' health and well-being are promoted.

In several studies it has been stated that functional and positively experienced co-operation and partnership between home and school have positive effects that promote the wellbeing and learning of pupils [14, 28]. Epstein and Sheldon (2002) have also found that several family-schoolcommunity partnership practices predict an increase in daily attendance, a decrease in chronic absenteeism, or both [13]. Additional needs for partnership with other sectors, like various community organizations, were identified [17]. In our previous study of health promotion in the Finnish ENHPS schools we found that collaboration in a network of participants from inside and outside the school community was the most commonly described positive event Planning and implementation of health promotion activities in collaboration with teachers, pupils, parents, school nurses and representatives of the municipals and parish youth work organizations and other comprehensive schools in a long lasting period was respected [29]. However, although many articles deal with partnership, to date few studies have explored the extent to which a relationship between schools and other community organizations truly exists [17].

The staff of the school has to have sufficient mental and skill resources, readiness and sufficient support for carrying out co-operation (see Fig. 1; Resources). Earlier studies show that the role of the headmaster and teacher $[27,30]$ and the school nurse [31-33] are importance, so that actions which promote health are possible in school communities. However, in the light of earlier studies, there are several obstacles in the background of the partnership between school and home. For example, teachers have few resources for co-operation even though parents hope for it [28]. Novice teachers may not have competence for co-operation [34]. New teachers do not often have enough know-how to concretely implement and develop partnership with parents. 


\author{
Health promotion \\ functions in the \\ school community
}

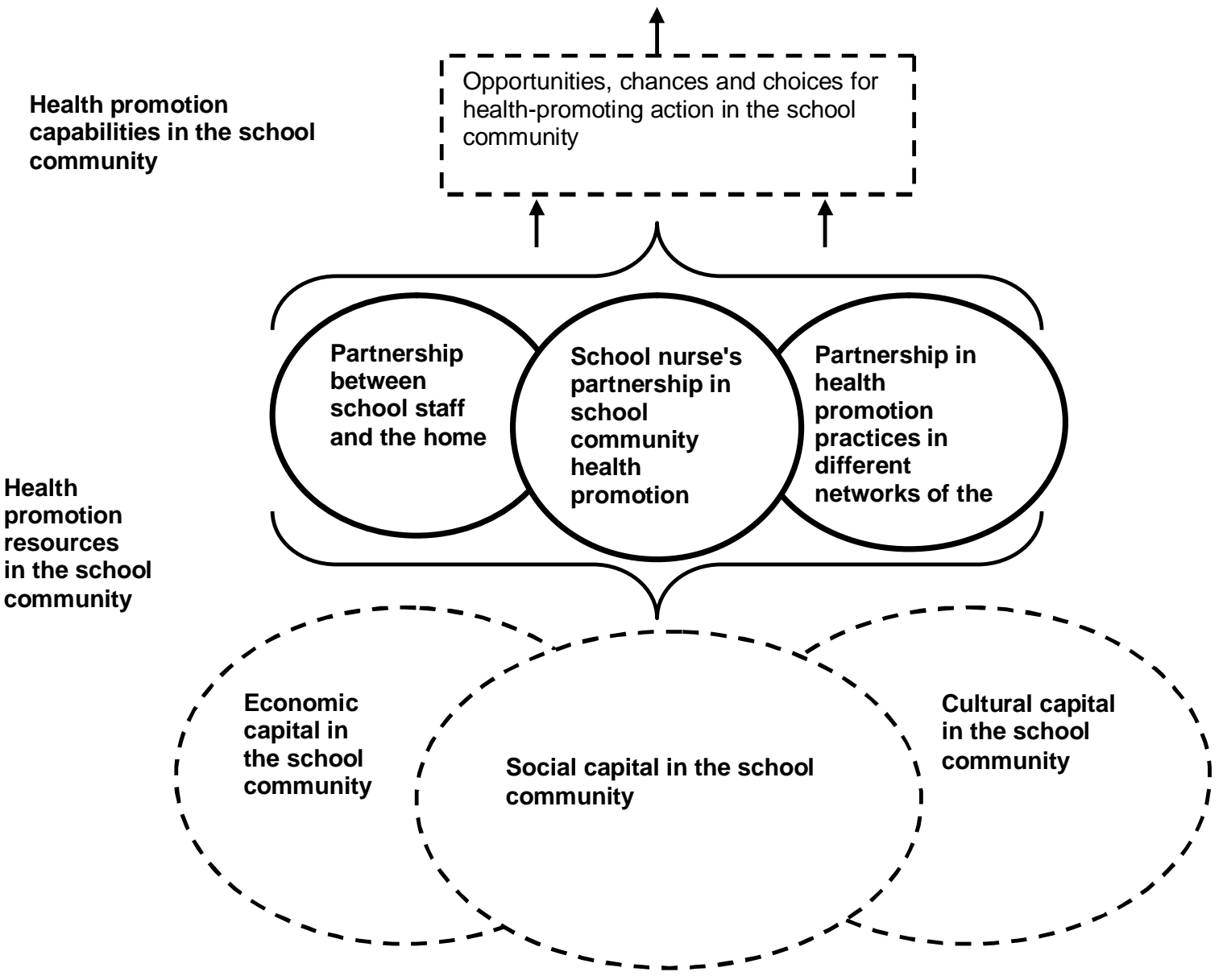

Fig. (1). Health promotion resources, capabilities and functions in the school community.

For successful partnership, the resources of all parties' must indeed be surveyed. Partnership also requires strong leadership, a common vision, intensive co-operation and scheduling [35]. Another problem is also that poor families usually participate in co-operation between the home and the school less than well-paid families. Thus, more communal and individual understanding of different kinds of families is needed in school communities, as well as enhancement of parents' social capital, so that they can direct their children better [28]. According to Virtanen and Onnismaa (2003), for example performance discussion is a suitable method of cooperation between home and school because it increases confidence between the parties; both parties get necessary information about each other [36]. However, partnership between schools, parents and other organizations is underdeveloped and undervalued, but it represents a potential way in which schools might built additional capacity and support [17].
Successful partnership and co-operation with the different levels of the school community are seen as affirmative resources for the health and well-being of children and adolescents, which provides resources and makes choices possible in the promotion of health. A final result is, for example, a healthy lifestyle and better health (see Fig. 1). However, social capital is not separate from other capital structures, such as cultural and economic capital, even though their handling has been consciously left with less mention in this article that concentrates on social capital, especially social support networks and partnership. For example, realisation of co-operation between home and school has to be a part of the operating culture of the school (cf. cultural capital) in which the workers have sufficient know-how to carry out partnership (cf. social capital). The social capital viewpoint of this study is especially a social support network, like home-school partnership, school nurse's partnership and also wider partnerships in the 
different levels of school communities, for the promotion of pupils' health and well-being. The study is part of a larger European Network of Health Promoting Schools programmed (ENHPS) in Finland. The objective of the study is to produce information that helps the staff of schools and partners in co-operation in the future to develop health promotion in the school community and to design partnership programmes at different levels of the school community to promote pupils' health in comprehensive schools.

\section{MATERIALS AND METHODOLOGY}

\section{Aims of the Study}

The aim of the study was especially to investigate Finnish ENHPS school teachers' (classes 1-9, $\mathrm{n}=22$ ) views of the functionality of the social support network in promoting children's health and well-being in school during the four-year period (2003-2006). We especially wanted to examine possible changes in (1) partnership between school staff and the home; (2) school nurse's partnership in the school community's health promotion; (3) partnership and co-operation in health promotion practices in different levels of school communities. Thus, this article deals with social capital as the resource of children's health and well-being.

\section{Data and Methods}

The ENHPS programme was an international programme for the promotion of school health initiated by the WHO European regional office, the European Council and the European Commission, to which more than 40 countries belonged in the years 1991-2007 [37]. Since 2008 the Schools for Health in Europe (SHE) network has continued the mission of ENHPS [1,38]. Finland joined the ENHPS programme in 1993 and since then a varied number of Finnish schools (30-70 schools) have been involved in the ENHPS / SHE programmes [31]. The ENHPS / SHE aims are to integrate health promotion into every aspect of the curriculum, introduce healthy programmes and practices into everyday school routines, improve working conditions and foster better relations both within the schools and between them and their local communities. The reason behind the idea of integrating health promotion into every aspect of the school setting is the vision that everybody will be connected with it: pupils, teachers, other school staff, parents and, eventually, the wider community $[1,39]$.

The data for the study were collected at the beginning and end of the four-year (2003-2006) ENHPS period. Altogether 22 school communities (= participants) took part in both the basic and follow-up surveys. The response rate was $53 \%$. The participants were teachers or school directors who also worked as health-promoting school coordinators at their school level.

We used web-based questionnaires, which consisted of Likert-type items $(1=$ strongly agree/positive, 2 = somewhat agree/positive, $3=$ don't know, $4=$ somewhat disagree/negative, $5=$ strongly disagree/negative). The questionnaire was formulated based on literature including items related to partnership between school staff and home school nurse's partnership in the school community and partnership in health promotion practices in school community. The data were analyzed using descriptive statistics. The alternative responses "strongly agree" and "somewhat agree" were combined into a new alternative "agree", and "strongly disagree" and "somewhat disagree" were combined into a new alternative "disagree". Possible differences between the beginning and end of the four-year period during which the participating Finnish ENHPS schools belonged to the Network were examined by means of a non-parametric Wilcoxon's signed rank test. A nonparametric test was used because of the small number of cases. A result with a $p$-value of less than 0.05 was regarded as statistically nearly significant, a $p$-value of less than 0.01 as significant and a p-value of less than 0.001 as highly significant [40].

\section{Ethical Questions}

This study was implemented using good scientific practice formalised by the Finnish National Advisory Board on Research Ethics, which promotes research ethics in Finland [41]. Ethical approval was applied for from the Finnish ENHPS board and the participants were given information about the purpose of the study. Participation in the study was voluntary and anonymous

\section{RESULTS}

\section{Partnership Between School Staff and the Home}

Table 1 presents the results of the partnership between school staff and the home, which was considered successful overall. The teachers estimated that the school supported the educational task of the homes and were responsible for the pupils' growth and education $(90 \%$ in 2004 and $91 \%$ in 2006). Nearly all the schools $(90 \%$ in 2004 and $95 \%$ in 2006) worked in co-operation with the parents at an individual as well as at the parent-society level so that the parents could support the target-oriented learning and school attendance of their children. A pupil welfare network and a multi-vocational co-operation network had been arranged at nearly all the schools (100\% in 2004 and $95 \%$ in 2006), so that it was possible to use them to support the pupils' school attendance and well-being.

At the curriculum level, development was still needed in the definition of co-operation between home and school. When planning a curriculum, co-operation between school and home was not always defined together with the social welfare and public health service authorities of the municipality. Nonetheless, at the beginning of the period $43 \%$ and in the follow-up situation $68 \%$ of the teachers estimated that co-operation was defined together with the social welfare and public health service authorities of the municipality.

The pupils' supporters did not always have opportunities to participate in the planning and evaluation of teaching and educational work together with a teacher and pupils. Namely, in the beginning approximately one fifth of the teachers $(19 \%)$ and one third of them $(32 \%)$ in the follow-up disagreed that the supporters had opportunities to participate in the planning and evaluation of the teaching and educational work of the school together with a teacher and pupils. The situation was described in open-ended comments as follows: "When preparing / planning the curriculum there is always a horrible hurry, so the teachers usually do it and then the parents are perhaps sometimes able to become 
Table 1. Partnership Between School Staff and the Home (N=22,\%)

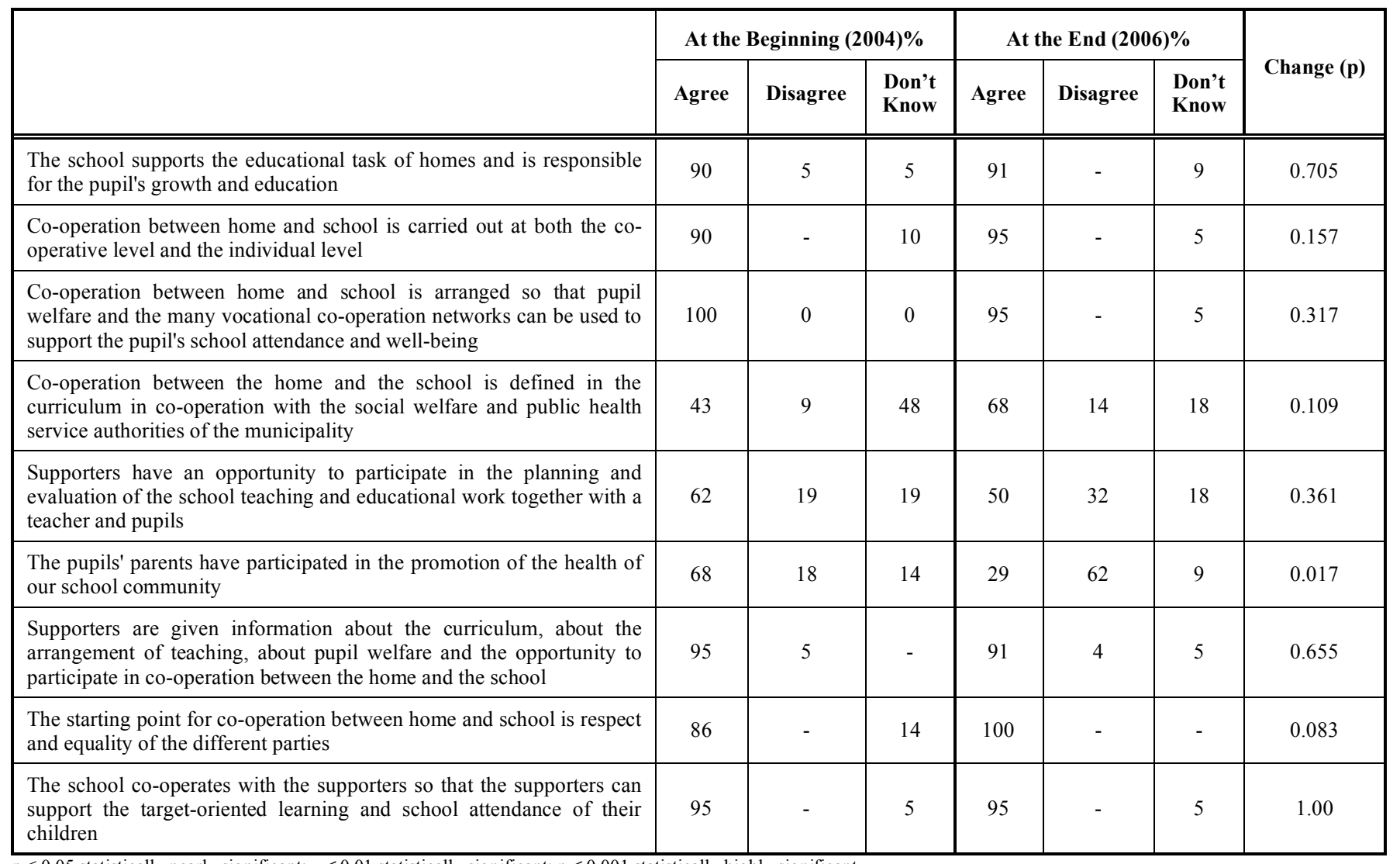

$\mathrm{p} \leq 0.05$ statistically nearly significant; $p \leq 0.01$ statistically significant; $\mathrm{p} \leq 0.001$ statistically highly significant.

acquainted with it if they are interested in it, particularly on the upper level. The parents have not influenced the curriculum of health education at all."

The teachers estimated that parents' participation in the promotion of health in the school decreased from $68 \%$ parents' participation to $29 \%$ during the follow-up time, which is a statistically significant finding $(\mathrm{p}=.017)$. However, in the participants' opinion, the parents $(95 \%$ in 2004 and $91 \%$ in 2006) were informed about the curricula, about the teaching arrangements, about pupil welfare and about the opportunity to participate in the co-operation between the home and the school. The starting point for the co-operation between home and school was respect for and equality of the different parties (86\% in 2004 and $100 \%$ in 2006). Furthermore, nearly all the participants $(95 \%$ in 2004 and 2006) felt that the school was in co-operation with the supporters so that the supporters could support the targetoriented learning and school attendance of their children.

\section{SCHOOL NURSE'S PARTNERSHIP IN THE SCHOOL COMMUNITY'S HEALTH PROMOTION}

A majority of the teachers (73\% in 2004 and in 2006) estimated that the expertise of the school nurse was used by the staff of the school, if necessary (Table 2). However, over a fourth (27\% in 2004 and in 2006) disagreed on the claim in question. The participation of the school nurse in teaching and the planning of teaching was also considered minor. At the beginning of the period one fifth $(18 \%)$ and in the follow-up situation nearly half $(45 \%)$ of the teachers estimated that the school nurse did not participate in health education actively. Furthermore, less than a third $(27 \%$ in 2004 and $32 \%$ in 2006) estimated that the school nurse did not participate actively in the compilation of the curriculum of health promotion. Most shortcomings appeared in participation in the decision-making of the school nurse: $36 \%$ of the participants in 2004 and as much as 59\% in 2006 informed that the school nurse did not participate actively in decision-making concerning the school community. However, the school nurse was seen to have a more active role in the evaluation of the physical and psychosocial working conditions of the school and in the promotion of well-being. Yet, $18 \%$ of the teachers at the beginning of the period and $14 \%$ in the follow-up situation considered the role of the school nurse inadequate here.

We wanted to find out the participants' views on cooperation between the teachers and the school nurse in the promotion of health with the help of the open question. In these answers co-operation was described as smooth and flexible: "Succeeds well, school nurse is active, his/her professional skill is trusted", "Does work naturally and flexibly". The professional skill of the school nurse was trusted and the teachers experienced that they were getting support in the different matters which are related to health and well-being: "Even though the school nurse's room is in a separate building, it seems that co-operation goes well and that, if necessary, we get support and help."

In some of the schools the school nurse also belonged to different teams and took part in planning of special topic days: "The school nurse joined the pupil welfare work group 
Table 2. School Nurse's Partnership in the School Community's Health Promotion $(\mathrm{N}=\mathbf{2 2}, \%)$

\begin{tabular}{|c|c|c|c|c|c|c|c|}
\hline & \multicolumn{3}{|c|}{ At the Beginning (2004)\% } & \multicolumn{3}{|c|}{ At the End (2006)\% } & \multirow{2}{*}{ Change (p) } \\
\hline & Agree & Disagree & $\begin{array}{l}\text { Don't } \\
\text { Know }\end{array}$ & Agree & Disagree & $\begin{array}{l}\text { Don't } \\
\text { Know }\end{array}$ & \\
\hline $\begin{array}{l}\text { The health expertise of the school nurse is always at the disposal of the } \\
\text { staff of our school, if necessary }\end{array}$ & 73 & 27 & - & 73 & 27 & - & 1.000 \\
\hline The school nurse participates actively in health education & 68 & 18 & 14 & 55 & 45 & - & 0.086 \\
\hline $\begin{array}{l}\text { The school nurse participates actively in compiling the curriculum of } \\
\text { health promotion }\end{array}$ & 50 & 27 & 23 & 59 & 32 & 9 & 0.885 \\
\hline $\begin{array}{l}\text { The school nurse participates actively in decision-making (for } \\
\text { example, at teachers' meetings etc.) concerning the school community }\end{array}$ & 59 & 36 & 5 & 41 & 59 & - & 0.108 \\
\hline $\begin{array}{l}\text { The school nurse participates actively in the evaluation of the physical } \\
\text { and psychosocial working conditions of our school and in health } \\
\text { promotion }\end{array}$ & 77 & 18 & 5 & 77 & 14 & 9 & 0.783 \\
\hline
\end{tabular}

$\mathrm{p} \leq 0.05$ statistically nearly significant; $p \leq 0.01$ statistically significant; $\mathrm{p} \leq 0.001$ statistically highly significant.

every week. The essential task of the team is the promotion of health in our school. Every day the school nurse is in close co-operation with the class supervisors in matters related to the pupils' health and well-being. The pupils can meet the school nurse every day", "The school nurse participates as far as possible in the planning of the special topic days and sometimes also in their realization."

Factors that affect co-operation negatively were also brought out in the open answers. Especially the lack of time and the large amount of work of the school nurse were seen as factors that weaken co-operation. It was not necessarily possible to catch the school nurse every day, which for its part made the smoothness of co-operation more difficult: "Co-operation is close and smooth. The school nurse tends to be overloaded, really busy." "The problem is the school nurse's lack of time at our school: 3 days per month." "The school has the school nurse present three days per week. He/she takes part in the pupil welfare work group and is always at the teachers' disposal according to the resources." The results bring out the great variation in the resources of the school nurse in different schools.

\section{PARTNERSHIP IN HEALTH PROMOTION PRACTICES IN DIFFERENT LEVELS OF THE SCHOOL COMMUNITIES}

Table 3 indicates that much vocational co-operation in health promotion at school has been successful. Based on the results, the majority of the teachers $(86 \%)$ at the beginning of the period and in the follow-up situation $(90 \%)$ estimated that co-operation with experts in different fields (for example, teachers, school welfare officers, psychologists, school nurses, etc.) has been flexible. However, co-operation with members of the school community in the compilation of the curriculum of the promotion of health was not implemented very generally yet. Less than half of the participants (48\% in 2004 and $40 \%$ in 2006) estimated that not all the members of the school community (the teachers and staff of the school, the pupils and other parents) actively participated in the promotion of health in the compilation of the curriculum. Furthermore, dissatisfaction with the activity of the persons compiling the curricula of health promotion increased significantly during the study period $(38 \%$ dissatisfied in 2004 and $60 \%$ in 2006, $p=0.043$ ).
Co-operation in the promotion of the health with the public service branches of the locality was extremely abundant (95\% in 2004 and $100 \%$ in 2006). The schools also co-operated much with organisations in the locality or neighbouring areas (for example MLL) at the beginning of the period $(91 \%)$ and in the follow-up situation $(86 \%)$. While $68 \%$ of the schools in 2004 had co-operated with other schools in the locality in the promotion of health, in 2006 the percentage had fallen under $48 \%$.

There was considerably less regional co-operation between schools. Only a quarter of the schools had cooperated in the promotion of health with schools in other localities of the region at both study times (23\% in 2004 and $28 \%$ in 2006). However, about half of the schools cooperated at the national level with other schools in the promotion of health $(50 \%$ in 2004 and $55 \%$ in 2006). At the international level $41 \%$ of the schools had co-operated in the promotion of health at the beginning of the period and $29 \%$ in the follow-up situation.

\section{DISCUSSION}

The research results of the four-year follow-up show that parents' participation in co-operation between home and school requires development (cf. Table 1). According to the research results, participation of the pupils' parents in the promotion of the health of the school community has diminished statistically significantly. The results also show that the supporters' opportunities to participate in the planning and evaluation of the schools' teaching and educational work together with the teachers and pupils has weakened, even though the Basic Education Act 628/1998, revision 477/2003 and the National Core Curriculum for Basic Education (2004) standardise teaching, education and co-operation in the objectives of the curriculum of the school as being tasks of both the school and the home $[6,11,12]$.

Also earlier research results of international studies bring out shortcomings in the co-operation between the home and the school in the support of the health learning and wellbeing of pupils $[14,15,28,34]$. Several factors may be behind the scantiness of co-operation between home and school; it is difficult for parents to commit themselves to the responsibility or it is not known how to decentralise 
Table 3. Partnership in Health Promotion Practices in Different Levels of School Communities (N=22,\%)

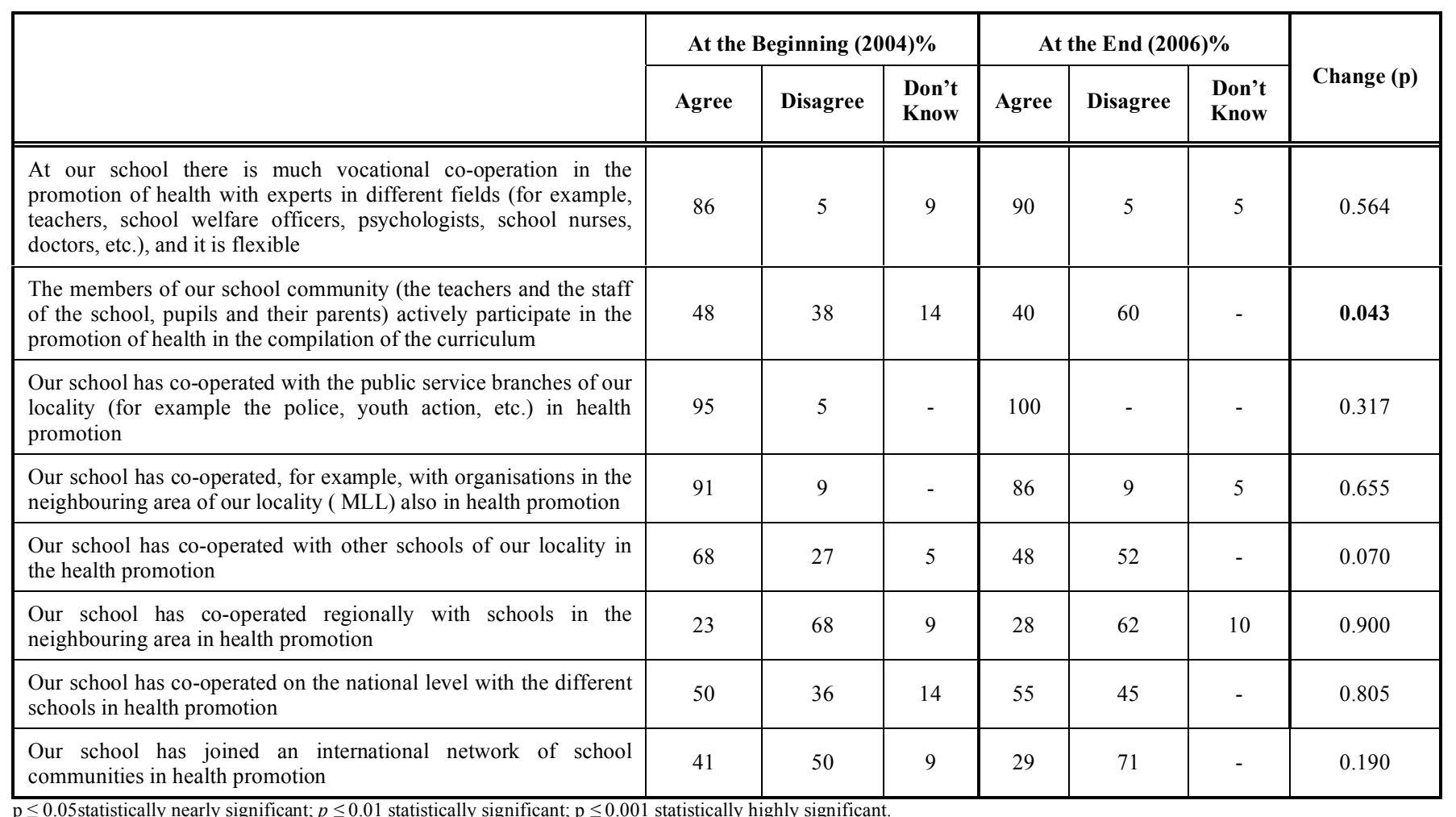

responsibility so that the same parents need not be active all the time. Although co-operation between parents and the school is active as a rule and natural (for example, the parents participate in parents' evenings and other activities of the school), based on the results $60 \%$ of the teachers felt that the staff of the whole school, parents and pupils do not actively participate in the promotion of health in compiling the curriculum (cf. Table 3). However, according to the national principles of the curriculum, such co-operation is supposed to take place.

Of course, parents are represented, for example, on the board of directors and/or the pupil welfare work group of the school, but the curriculum of the school that has been drawn up is brought to them ready to be accepted. At school it is felt that when the information of the curriculum has been drawn up it is sufficient to bring it to the representatives of parents and it is not necessary to summon the parents to participate in the compilation process and the development process of the curriculum. Thus, the health questions of the pupils and health education may receive minor attention in the curriculum if the parents cannot bring out the matters of the health learning of their child from the point of view of the family already in the planning stage.

The significance of the school nurse is important when the health of the pupils is promoted, as when developing programs on obesity, drug use, or depression to promote mental health and increase academic achievement [32]. However, the school health staff does not produce sufficient support services for the school in promoting the health and well-being of the pupils (see Table 2). According to this study the expertise of the school nurse in the questions of promoting health and in expanding the promotion of health in school communities is considered strong, but the resources are often too small at schools. Furthermore, there is great variation in the resources of the school nurse in different school communities. The work of the school nurse is concentrated on the pupil's physical examinations and the school nurse has no operational resources for perceiving and finding sudden health threats of a pupil. There indeed are references to the fact that the responsibility for perceiving pupils' health threats has been transferred to the teacher, who is also responsible for further reporting observations to the school nurse. Likewise, the role of the school nurse requires clarification in health promotion work and pupil welfare in the school community.

The expansion of the common social capital becomes an objective between the school (to contain the staff and a school nurse) and the home [22, 28]: what kinds of methods and operating models are there to help and to solve problems and shortcomings that are manifested in confidential interdependency and co-operation. Teachers' turnover at school also sets challenges to the continuity of co-operation and to the expansion of social capital. For example, Saaranen et al. (2007) found teachers' turnover in school communities to be significant in an action research project in which teachers' occupational well-being was developed in the school communities [42]. Promotion of the health and occupational well-being of the staff also supports the pupils' achievement of better learning results and the willingness of the teachers to develop their own work [42].

On the basis of the results the starting point for cooperation between the schools and the home is respect and equality of the different parties (see Table 1), but concrete co-operation between the parents and the school clearly requires strengthening in the promotion of health. Also, wider co-operation between home, school and community 
and with different co-operating partners requires targetoriented planning, which again calls for sufficient mental and skill resources, readiness and sufficient support to carry out co-operation by the staff of the school (see Fig. 1 Resources). Successful partnership in health promotion practices in different networks of school communities requires good leadership in the school community itself [35] and mutual partnership among the workers of the whole school (teachers, school nurse and other staff), which includes trust, open communication, interaction and learning and participation (cf. social capital).

Successful partnership inside the school community also prepares for wider co-operation in promoting the health and well-being of the pupils. Based on this study, multivocational co-operation between schools and experts in different fields of health promotion (for example, teachers, school welfare officers, psychologists, school nurses, doctors, etc.) and the public service branches of the locality (for example, the police, youth action) indeed is flexible (see Table 3). However, the results show that there is need for development in co-operation with other schools of the locality and neighboring areas.

Because the functionality of the social support networks is significant when promoting the health and well-being of children and adolescents $[13,22]$, new ideas and models for improving co-operation must be developed in a continuously changing society. Schools indeed should be target-oriented, for example in co-operation between the home and the school, in planning how in health education could utilize interactive learning tasks to allow children, parents and different schools to co-operate more than at present, for example in the web-based learning environment of the school's health education. In this way the parents' media skills can also be developed and they may become able to be more closely committed to supporting the teaching task and educational task of the school through similar objectives. Partnership programmes between the home and the school, which are suitable for the workday of the school, well designed and tried, are missing nearly entirely from Finland, and only a few are found internationally [17-19]. Thus, there is a need for development models with which to develop cooperation between the home and the school, which have been tested and evaluated in practice.

The questionnaire used in this study was used previously and the validity and reliability was found good [16]. The sample of schools consisted of only 22 schools in Finland, and therefore the results cannot be generalized widely. However, the results are suggestive for other schools elsewhere in Finland and the results can give new points of view also internationally for the development of pupils' health and well-being in school communities. The study indeed produced information which will help the staffs of schools and partners co-operate in the future in developing the promotion of the health of pupils in the school community and in designing partnership programmes at different levels of the school community to promote the children's and young people's health in comprehensive schools.

\section{CONCLUSION}

Social support networks, like partnership between the school staff and the home and the school nurse's partnership in the school community's health promotion, as a dimension of social capital, are ways to realize pupils' health and wellbeing. Furthermore, social capital is not separate from other capital structures, such as cultural and economic capital, which are all needed. Evidence-based, tested and suitable partnership programs targeted to children's positive health promotion in the school community are basically lacking in Finland. Thus, this study provides information about the functionality of social capital and about the situation of partnerships, which is valuable to the staff of the school, to co-operating partners and to researchers in developing health promotion in school communities.

\section{ACKNOWLEDGEMENTS}

This study has been carried out in co-operation with the Finnish European Network of Health Promoting Schools programme, as of 2008 the School for Health in Europe. The Finnish Centre for Health Promotion, which has co-ordinated the Finnish European Network of Health Promoting Schools programme, and all the members of the school staffs who participated in this study are warmly acknowledged. Without their contribution this study would never have happened.

\section{REFERENCES}

[1] School for Health in Europe. SHE strategic plan 2008-2012. [Retrieved 2010 Apr 14]. Available from: http://www.schoolsfor health.eu/

[2] Health Promotion Government Policy Programme. Policy programme for health promotion 2007. [Retrieved 2010 Apr 14]. Available from: http:/www.valtioneuvosto.fi/toiminta/politiikkaoh jelmat/terveys/ohjelman-sisaeltoe/en.pdf

[3] Children, Youth and Families Government Policy Programme. Policy programme for the well-being of children, youth and families 2007. [Retrieved 2009 Jun 4]. Available from: http://www. valtioneuvo sto.fi/toiminta/politiikkaohjelmat/lapset/ohjelman.sisae ltoe/en.pdf

[4] OECD Programme for International Student Assessment. PISA 2006 Science Competencies for Tomorrow's World 2007. [Retrieved 2010 Apr 14]. Available from: http://www.pisa.oecd. org/document/2/0,3343,en_32252351_32236191_39718850_1_1_ 1_1,00.html

[5] Currie C, Gabhainn SN, Godeau E et al., Eds. Inequalities in young people's health. Health behaviour in school-aged children international report from the 2005/2006 survey. Health policy for children and adolescents. No. 5. 2008, [Retrieved 2010 Apr 14]. Available from: http://www.euro.who.int/Document/E91416.pdf

[6] FNBE. National core curriculum for basic education. national core curriculum for basic education intended for pupils in compulsory education. Finnish National Board of Education 2004. [Retrieved 2010 Apr 14]. Available from: http://www.oph.fi/ops/ english/POPS_net_new_1.pdf

[7] Välimaa R, Kannas L, Lahtinen E, Peltonen H, Tynjälä J, Villberg J. Finland: innovative health education curriculum and other investments for promoting mental health and social cohesion among children and young people. In: WHO/HBSC FORUM 2007. Social cohesion for mental well-being among adolescents. Copenhagen, WHO. Regional Office for Europe 2008; pp. 91-103.

[8] Government Decree 614/2001 in Finland (in Finnish): Valtioneuvoston asetus opetustoimen henkilöstön kelpoisuusvaatimuksista annetun asetuksen 14 ja $28 \S:$ m muttamisesta. [Retrieved 2010 Apr 14] Available from: http://www.finlex.fi/fi/laki/alk up/2001/20010614.

[9] Salmivalli C, Kaukiainen A, Voeten M. Anti-bullying intervention: implementation and outcome. Br J Educ Psychol 2005; 75(3): 46587. 
[10] Sohlberg ME, Olweus D, Endresen IM. Bullies and victims at school: are they the same pupils? Br J Educ Psychol 2007; 77(2): 441-64.

[11] Basic Education Act 21.8.1998/628. [Retrieved 2010 Apr 23]. Available from: http://www.finlex.fi/fi/laki/ajantasa/1998/1998062 8

[12] Basic Education Act's Change 13.6.2003/477. Retrieved 2010 Apr 23, from: http://www.finlex.fi/fi/laki/alkup/2003/20030477.

[13] Epstein JL, Sheldon SB. Present and accounted for: improving student attendance through family and community involvement. J Educ Res 2002; 95(5): 308-18.

[14] BenArieh A, McDonell J, Attar-Schwartz S. Safety and homeschool relations as indicators of children well being: whose perspective counts? Soc Indic Res 2009; 90(3): 339-49.

[15] Epstein JL. Building bridges of home, school, and community: the importance of design. J Educ Stud Placed Risk 2001; 6(1\&2): 16168.

[16] Turunen H, Tossavainen K, Jakonen S, Vertio H. Did something change in health promotion practices? a three-year study of Finnish European Network of Health promoting Schools. Teach Teach Theor Pract 2006; 12(6): 675-92.

[17] Adderson-Butcher E, Stetler G, Midle T. A case for expanded school community partnership in support of positive youth development. Child Sch 2006; 28(3): 155-63.

[18] Shepard J, Carlson JS. An empirical evaluation of school-based prevention programs that involve parents. Psychol Sch 2003; 40(6): 641-56.

[19] Sar BK, Wulff DP. Family builders approach: enhancing the wellbeing of children through family-schools partnership. Child Sch 2003; 25(4): 241-51.

[20] Abel T. Cultural capital. J Epidemiol Commun Health 2008; 62(e13): 1-5.

[21] Hancock T. People, partnership and human progress: building community capital. Health Promot Int 2001; 16(3): 275-80.

[22] Ferguson KM. Social capital and children's well-being: critical synthesis of international social capital literature. Int J Soc Welfare 2006; 15(1): 2-18.

[23] Bourdieu P. The forms of capital. In: Richardson J, Ed. Handbook of theory and research for the sociology of education. Westport: Greenwood Press 1986; pp. 241-58.

[24] Eng PM, Rimm EB, Fitzmaurice G, Kawachi I. Social ties and change in social ties relation to subsequent total and cause-spesific mortality and coronary heart disease incidence in men. Am J Epidemiol 2002; 155(8): 700-9.

[25] Hyyppä MT, Mäki J, Impivaara O, Aromaa A. Individual-level measures of social capital as a predictors of all-cause and cardiovascular mortality: a population-based prospective study of men and women in Finland. Eur J Epidemiol 2007; 22(9): 589-97.

[26] Putnam RD. Making democracy work. Civic traditions in modern Italy. Princeton: Princeton University Press 1993.
[27] Saaranen T, Tossavainen K, Turunen H, Vertio H. Occupational well-being in a school community - staff's and occupational health nurse's evaluations. Teach Teach Educ 2006; 22(6): 740-52

[28] Hill NE, Taylor LC. Parental school involvement and children's academic achievement. Pragmatics and issues. Am Psychol Soc 2004; 13(4): 161-64.

[29] Turunen H, Tossavainen K, Vertio H. How can critical incidents be used to describe health promotion in the Finnish European Network of Health Promoting Schools? Health Promot Int 2004; 19(4): 41927.

[30] Cohall AT, Cohall R, Dye B, Dini S, Vaughan RD, Coots S Overhead in the halls: what adolescents are saying, and what teachers are hearing, about health issues. J Sch Health 2007; 77(7): 344-50.

[31] Tossavainen K, Turunen H, Jakonen S, Vertio H. Health promotion education: differences between school nurses' health counselling and teachers' health instructions in the Finnish ENHPS. Child Soc 2004; 18(5): 371-82.

[32] Puskar KR, Bernando LM. Mental health and academic achievement. Role of school nurse. J Spec Pediatr Nurs 2007; 12(4): 215-23

[33] Whitehead D. The health-promoting school: what role for nursing? J Clin Nurs 2006; 15(3): 264-71.

[34] Graue E, Brown CP. Preservice teachers' notions of families and schooling. Teach Teach Educ 2003; 19: 719-35.

[35] Cohen R, Linker JA, Stutts L. Working together: lessons learned from school, family and community collaboration. Psychol Sch 2006; 43(4): 419-28.

[36] Virtanen N, Onnismaa J. Performance discussions as a form of home-school cooperation. Finn J Educ Kasvatus 2003; 34(4): 35158

[37] Clift S, Jensen BB, Paulus P. Introduction. In: Clift S, Jensen BB, Eds. The health promoting school: international advanced in theory, evaluation and practice. Copenhagen: Danish University of Education Press 2005; pp. 9-20.

[38] Tang KC, Nutbeam D, Aldinger C, et al. Schools for health, education and development: a call for action. Health Promot Int 2008; 24(1): 68-77.

[39] Rasmussen VB, Rivett D. The European Network of Health Promoting Schools - an alliance of health, education and democracy. Health Educ 2000; 100(2): 61-7.

[40] Polit DF, Hungler BP. Nursing research. Principles and methods, $6^{\text {th }}$ ed. Philadelphia: Lippincott 1999.

[41] The National Advisory Board on Research. Ethics gives out reformed guidelines: good scientific practice and procedures for handling misconduct and fraud in science. [Retrieved $2010 \mathrm{Apr}$ 23]. Available from: http://www.tenk.fi/ENG/HTK/htkeng.pdf

[42] Saaranen $T$, Tossavainen $K$, Turunen $H$, Naumanen $P$. Development project (2001-2004) of school staff and occupational health nurses as a promoter of occupational well-being - staff's evaluations. Educ Res Eval 2007; 13(1): 17-52. 